\title{
Imunitní systém ve fyziologickém řádu organizmu
}

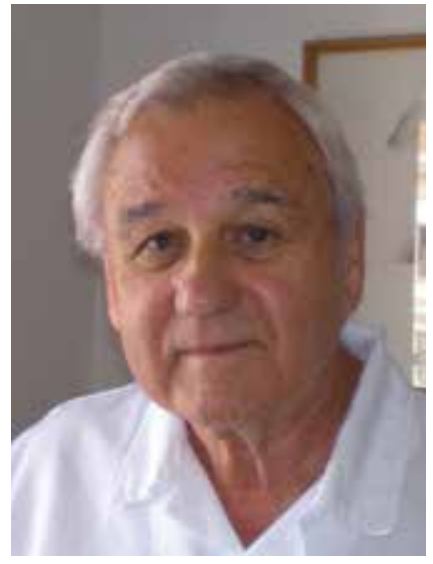

Živé soustavy jsou v biologii definovány jako systémy s cílovým chováním. Cílem je existovat v prostoru a v čase, tj. přežít. Cílové chování buňky a živých systémů má 2 stránky: sebeudržování a sebereprodukci. Sebeudržování zahrnuje také neporušenost, stálost, jedinečnost molekulární struktury organizmu, biochemický izolacionizmus. $V$ tomto aspektu se uplatňuje imunitní systém.

Tradičně se odlišuje systém vrozené (přirozené, nespecifické) imunity a systém adaptivní (získané, specifické) imunity. Zásadní rozdíl spočívá v tom, že senzory vrozené imunity jsou zakódovány v genech zárodečné linie, u nichž nedochází k přeskupování, a tudíž vytváření jejich variant, zatímco senzory, prostřednictvím nichž se systém adaptivní imunity orientuje ve světě „antigenư", jsou zakódovány v genech, u nichž dochází v průběhu života k přeskupování, a tak k vytváření jejich rozsáhlé rozmanitosti. Imunitní mechanizmy zajištující vrozenou a adaptivní imunitu jsou však integrovány, doplňují se a jsou na sobě závislé, tvoří funkční celek. Při posuzování fyziologie a zvláště patologie imunity je tudíž žádoucí vycházet z pojetí spojeného, jednotného imunitního systému.

Zásadně nový pohled na fyziologii imunitního systému přinesly práce, které objasňují molekulárně-genetickou podstatu vrozeného imunitního systému a dokazují jeho propojení se systémem imunity adaptivní. Hovoří se dokonce o novém imunologickém paradigmatu. Impulz dal Charles A. Janeway jr [1]. Receptory vrozené imunity (Pattern Recognition Receptor - PRR) jsou humorální, př́tomné v cirkulaci, např. lektin vázající manózu (Mannose-Binding Lectin - MBL), a některé další složky komplementového systému, a buněčné. $V$ centru pozornosti jsou receptory buněčné, které jsou v membráně i uvnitř buněk. Nejznámějšími jsou TLR (Toll-Like Receptory) a NLR (NOD-Like Receptory; NOD = Nucleotide Oligomerization Domain), které jsou součástí tzv. inflamasomů. Ligandami pro tyto receptory jsou jednak exogenní PAMP (Pathogen Asociated Molecular Pattern), jednak endogenní DAMP (Damage Associated Molecular Pattern). Výraz „pattern“ se překládá jako vzor, vzorec, motiv, signatura. Konkrétně, PAMP jsou molekulární struktury mikrobů (proto se někdy setkáme i s akronymem MAMP) odlišné od molekulárních struktur hostitele. Jsou nevariabilní, společné skupinám mikroorganizmů a nezbytné pro jejich životnost a patogenitu. Patří k nim např. lipopolysacharidy, peptidoglykany, manany, nemetylované motivy CpG DNA, dsRNA a další. DAMP jsou endogenní molekuly, které pocházejí z poškozených a odumírajících buněk; patří k nim např. krystaly kyseliny močové, extracelulární ATP, fragmenty fibrinogenu, hyaluronan, proteiny teplotního šoku a další. Interakce PRR s PAMP nebo DAMP vyústí v zánětlivou reakci. Dokladem uznání významu těchto objevů bylo udělení Nobelovy ceny za fyziologii nebo medicínu v roce 2011: Bruce A. Beutler a Jules A. Hoffmann ji dostali za objevy týkající se aktivace vrozené imunity, Ralph M. Steinman za objev dendritických buněk a jejich úlohy v imunitě adaptivní.

V tomto čísle časopisu Vnitřní lékařství přichází s moderním a inspirativním pohledem na zánětlivou reakci Jan Krejsek (Zánět obranný a poškozující). Vidí úlohu imunitního systému jako „integrální součást obranného i poškozujícího zánětu na genové, molekulové a buněčné úrovni“ a zastává přesvědčení, že „poznání obranného a poškozujícího zánětu nám poskytlo důkazy, že imunitní systém je podstatnou součástí patofyziologie mnohých stavů, u kterých jsme to ještě donedávna nepředpokládali“. Ilja Stř́ž se ve svém článku Cytokiny IL1 rodiny u chronických zánětlivých procesů zabývá účastí cytokinů při imunitních reakcích. Zaměřil se na rod IL1, do něhož patří faktory prozánětlivé i protizánětlivé. Pro praxi je velmi zajímavá zmínka o možnostech terapeutického ovlivnění IL1.

Nejznámějšími představiteli imunitního systému jsou bezesporu lymfocyty. Připomeňme si Niels Kaj Jerneho, který ve své nobelovské přednášce uvedl, že „náš imunitní systém je orgán složený z asi $10^{12}$ lymfocytů“ [2]. Úsměv možná vyloudí slova histopatologů v polovině minulého století, že „lymfocyt je flegmatický vagant, bloudící organizmem a tupě přihlížející bouřlivé činnosti mikrofágů“. Milan Buc nazval svůj článek Heterogenita lymfocytov ako ústredných operačných jednotiek imunitného systému. Popisuje současný stav poznání lymfocytárních subpopulací $\mathrm{B}, \mathrm{T}$, ale také nekonvenčních NK, NKT a MAIT a nevyhnul se ani recentně diskutovaným přirozeným lymfoidním buňkám (ILC). Text je dopIněn velmi přiléhavými tabulkami a obrázky.

Poslední desetiletí jsme v lékařské literatuře svědky až skoro explozivního růstu poznatků o "nepatogenním" vztahu mezi mikroby a hostitelem. Došlo k renesanci problematiky tzv. normální, fyziologické mikroflóry, zdưrazňuje se "komensalizmus", "mutualizmus", i v seriózních biologických časopisech se píše o tom, že člověk se svými mikroby je vlastně „superorganizmus“, že „kompletní já“ jsem já a mé mikroby. S uznáním vzpomeňme na pražskou imunologickou školu, jejímž z nejvýraznějších představitelů byl prof. J. Šterzl (1925-2012), který založil gnotobiologickou stanici v Hrádku již v 60. letech minulého století a zahájil experimenty s bezmikrobními zvířaty. Jeho spolupracovníci, Jiří Kruml a Ivo Miler napsali knihu Život bez mikrobů (Praha: Orbis 1975), v níž je již tehdy uvedeno: 
„Člověk hned po narození už není jen sám sebou. Lidský organizmus se stává gigantickým sídlištěm pro miliardy mikroorganizmů. ... Soužití hostitele s mikroorganizmy je výsledkem oboustranných adaptací, které se v průběhu věků neustále vyvíjely a zdokonalovaly“. Do tohoto čísla časopisu Vnitřní lékařství přispěla následovnice prof. Šterzla Helena Tlaskalová se svými žáky článkem Mikrobiota, imunita a imunologicky mediované choroby. Autoři dokládají, že „alterace vzájemného vztahu mikrobioty a hostitele vede k vývoji zánětlivých, autoimunitních i nádorových chorob a že pro medicínu budoucnosti se otevírají nové možnosti ovlivnit mikrobiotu nejen změnou životního stylu a způsobu stravování, ale i přímou manipulací s ní." Zvlášt diskutovaným problémem je účinnost tzv. probiotik. Speciálně na alergie je zaměřen článek dř́vější [3]. Kvưli úplnosti dodejme, že mikrobiom nejsou jen bakterie, ale jsou v něm i archaea, houby a viry.

Jednou z nejčastějších diagnóz, s níž přicházejí pacienti do ambulance klinické imunologie, je (suspektní) imunodeficience. Nápadná bývá zvýšená vnímavost resp. citlivost k infekčním agens. Infekce se opakují, trvají dlouho, probíhají těžce, špatně odpovídají na antibiotickou léčbu. Jiří Litzman ve svém článku Primární imunodeficience u dospělých dokládá, že pacienti s vrozenou, primární nedostatečností imunitního systému nejsou výsadou pediatrů, ale že významný počet $z$ nich je léčen, a někdy i teprve diagnostikován až v dospělosti. Primární imunodeficience patří mezi tzv. vzácné choroby. $V$ Česku je registrováno na 1000 pacientů. Nepoměrně častější jsou imunodeficience sekundární. Uvádí se, že AIDS, chemoterapie nádorů, imunologické choroby, transplantace přispěly v posledních několika dekádách k enormnímu globálnímu zvýšení počtu lidí s oslabenou imunitou - pravděpodobně to bude více než $1 \%$ světové populace [4]. Na Problematiku sekundárních imunodeficiencí jako následku chronických onemocnění se zaměřuje Zita Chovancová. Poukazuje na jejich nesourodost, uvádí nejčastějši prríčiny, na něž by měl všeobecný lékař i internista myslet, a zamýšlí se nad terapií, která se musí opírat zejména o léčbu základního onemocnění, ale jejiž součástí může být i imunoterapie.

Nejčastějšími primárními imunodeficiencemi jsou agamaglobulinemie a hypogamaglobulinemie. Také u některých nemocných s imunodeficiencemi sekundárními se setkáváme s poklesem koncentrace imunoglobulinů, které se odrážejí v jejich klinické symptomatologii. Základem léčby pacientů s různými formami hypogamaglobulinemie je imunoglobulinová substituce. Jí je věnován článek Jiř́ho Litzmana Léčba humorálních imunodeficiencí. Je zde zdůrazněn individualizovaný přistup (saturační dávky, udržovací dávky, rychlost infuze) a uvedeny praktické zkušenosti s intravenózním a subkutánním podáváním. Nežádoucí účinky imunoglobulinové léčby nazvali svůj příspěvek Iva Šutová, Zita Chovancová a Jiří Litzman. Opírají se o své klinické zkušenosti i o údaje ze světové literatury. Jejich návrh, jak zvládnout nežádoucí reakce, bude cenný i pro lékaře, kteří využívají imunoglobulinové preparáty jako imunosupresiva. Zvýšená poškozující reaktivita imunitního systému je indikací terapie imunosupresivní. Hlavními př́klady jsou transplantace buněk, tkání a orgánů, při nichž dochází k odvržení štěpu a autoimunitní, příp. antiinflamační choroby, a reakce imunitního systému se obrací proti vlastním strukturám. Marta Sobotková a Jiřina Bartůňková ve svém článku Trendy v imunosupresivní léčbě dávají nahlédnout do výzkumných projektů v této oblasti a kriticky hodnotí její současné možnosti i očekávání. Dủraz je kladen na bezpečnost, selektivitu a specifičnost imunosupresivních léků.

Podle memoranda WHO/IUIS/IAACI je „klinická imunologie klinický a laboratorní obor, zabývající se studiem, diagnostikou a léčením pacientů trpících chorobnými procesy způsobenými poruchami imunologických mechanizmů a chorobami, u nichž je ovlivňování imunity důležitou součástí léčby a prevence“. V souladu s Evropskou unií lékařských specialistů je u nás specializačním oborem „alergologie a klinická imunologie“. Specialisté jsou garantem komplexní klinické péče o nemocné s alergologickými a imunologickými chorobami. Místo alergologie a klinické imunologie je v interním lékařství nezpochybnitelné. O tom přesvědčivě píše ve svém článku Co dnes znamená alergologie pro internu a naopak Petr Čáp. Jak bylo uvedeno v časopisu Světové alergologické organizace, jestliže si uvě-

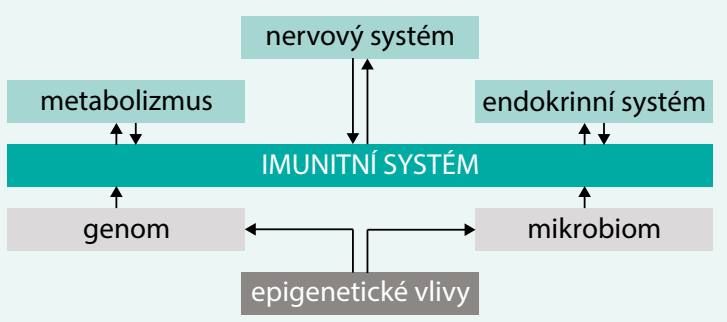


domíme, že asi 22 \% populace trpí na alergické a imunologické choroby, je nejvyšší čas uznat a zesílit výuku alergologie a imunologie [5]. Mimořádně závažným problémem nejen v alergologii, ale i v dalších lékařských oborech jsou alergie život ohrožující. Irena Krčmová a Jakub Novosad se ve svém článku Anafylaktické př́znaky a anafylaktický šok zhostili tohoto problému dovedně. Začínají epidemiologií, pokračují etiologií a patogenezí, zvlášt’ uvádějí anafylaxi, která není zprostředkovaná lgE, zasvěceně popisují klinickou manifestaci, diagnostiku, léčbu a prevenci.

Už v začátečním období rozvoje imunologie se ozývaly hlasy, že na imunitu je třeba se dívat v kontextu celého organizmu. Tak např. F. M. Lehmann píše, že „velké otázky imunity nelze oddělovat od otázek fyziologie a patologie“ [6]. Tohoto aspektu imunity se dotýká článek Zity Chovancové o imunodeficiencích u chronických chorob.

Schéma názorně ukazuje a současně zdůrazňuje nejen fakt, že imunitní systém je integrální součástí celého organizmu a je ovlivňován vlastním genomem i genetickou výbavou fyziologické mikrobioty, úrovní metabolizmu, činností endokrinního a nervového systému, ale též skutečnost, že organizmus je integrální součástí ekosystému, ovlivňován biodiverzitou, fyzikálním a chemickým stavem prostředí, možnostmi výživy, ohnisky infekčních chorob.

Výkonnost, účinnost, hospodárnost, pohotovost, výdrž imunitního systému lze označit jako imunologickou zdatnost, "fitness".

Na rozdílech v reálné výkonnosti imunitního systému se podílí sexuální dimorfizmus. Připomeňme si svého času populární Hegglinovu diferenciální diagnostiku interních chorob, v níž je jen kratičká zmínka, že „pohlaví má vliv na všechny životní projevy, a tedy i na reakci na choroboplodné činitele. Mnohé nemoci jsou častější u mužů a jiné zase u žen, aniž je příčina tohoto jevu v každém jednotlivém případě dostatečně známá" [7]. Rozdíly v imunologické reaktivitě na základě pohlaví se týkají jak vrozené, tak adaptivní imunity a odrážejí se ve výskytu vrozených imunodeficiencí, v prevalenci autoimunitních chorob, v prevalenci a na průběhu alergických chorob, v odlišné odpovědi na vakcíny. Vyšší náchylnost k infekčním nemocem je popisována u mužů, výrazně vyšší výskyt autoimunitních, ale i alergických chorob je znám u žen, které také intenzivněji reagují na vakcinaci. Při hledání př́ičin imunologických rozdílů žen a mužů je zaměřována pozornost především na endokrinní odlišnosti. Buňky systému vrozené i adaptivní imunity mají receptory také pro hormony, estrogeny i testosteron. Estrogeny ovlivňují imunologickou kompetenci aktivací receptorů, které jsou přítomny na buňkách T, B, dendritických, NK, makrofázích, neutrofilech. Základní parametry imunity se mění v průběhu menstruačního cyklu a zvlášt výrazně v těhotenství. Účinky estrogenů na zánětlivou reaktivitu může být různý. Androgeny, podobně jako estrogeny, ovlivňují imunologickou reaktivitu aktivací receptorů, které jsou př́tomny v cytoplazmě i jádru buněk imunitního systému. Převládá účinek protizánětlivý a imunosupresivní [8].

Imunologická reaktivita je ovlivněna i věkovým faktorem. Výkonnost vrozených i adaptivních imunitních mechanizmů se dotvárí v intrauterinním, novorozeneckém, kojeneckém a batolecím období působením faktorů ve vnitřním i zevním prostředí. Imunitní systém s věkem postupně chřadne, uvadá. V odborné literatuře se ustálil pojem imunosenescence: podstatou tohoto stavu je dysregulace imunitního systému, na níž se podílí involuce primárních lymfoidních orgánů i poruchy tvorby, zrání, migrace, homeostázy buněk imunity. Stárnutí je spojeno s chronickým prozánětlivým stavem, který se nazývá inflammaging. V důsledku zmnožení DAMP v stárnoucím organizmu se udržuje chronický, mírný, sterilní zánět. Projevuje se zvýšením produkce prozánětlivých i protizánětlivých cytokinů (IL6, TNFa, IL1ß, IFNү, IL10) především mononukleárními fagocyty, ale též buňkami svalové a tukové tkáně [9]. Nápadná je velká variabilita jednotlivých laboratorních parametrů imunity, která odráží známé interindividuální rozdíly v imunologické reaktivitě u starých osob.

Vynořila se nová oblast na rozhraní imunity a metabolizmu, imunometabolizmus. Je dokazována souvislost systému vrozené i adaptivní imunity s obezitou, metabolickým syndromem, kardiovaskulárními chorobami, procesy neurodegenerativními. Zajímavý je v této souvislosti i fakt, že imunitní systém patři vedle mozku a svalstva mezi hlavní odběratele energie $v$ těle. Zahájení a rozvoj imunitních reakcí je metabolicky náročné a nemůže probíhat v podmínkách energetického deficitu optimálně. Poznání molekulární podstaty imunologicko-metabolického dialogu slibuje prínos i pro praktickou medicínu, při zajištování optimální nutrice u pacientů s různými chorobami. Interakce mezi imunitním systémem a metabolizmem jsou vzájemné: metabolizmus ovlivňuje imunologickou reaktivitu a imunitní systém ovlivňuje metabolizmus. K fyziologickým funkcím imunitního systému tak patří i regulace systémové metabolické homeostázy, podpora "metabolického zdraví" [10,11].

Interakce mezi imunitním, nervovým a endokrinním systémem jsou mnohovrstevné. Buňky imunitního i nervového systému mají společné antigeny, receptory pro neurotransmitery, hormony, cytokiny. Buňky imunitního systému jsou schopny tvořit řadu neuroendokrinních substancí, vzájemné vztahy jsou zprostředkovány také přímou inervací lymfatických tkání. Pozornost přitahuje cholinergní protizánětlivá dráha: nervový systém může inhibovat uvolňování cytokinů prostřednictvím vagového zánětlivého reflexu, a tak tlumit poškozování tkání. Je uváděno, že T-lymfocyty produkující ve slezině acetylcholin, jsou integrální složkou nervového informačního systému, který kontroluje vrozenou, zánětlivou imunitní reakci [12]. Klinicko-imunologické aspekty souvislostí endokrinní a nervové soustavy s imunitním systémem jsou velmi pěkně popsány v monografii Krejska, Andrýse a Krčmové [13].

Vztahům mezi psychikou a imunitou se věnují Höschl a Horáček v článku př́hodně nazvaném Duše jako imunomodulátor [14]. 
V začátcích formování samostatného oboru klinické imunologie a jejího začleňování do zdravotnického systému koncem 70. let minulého století jsem vyslovil názor, že „klinická imunologie by měla být mostem spojujícím břehy teoretického oboru a lékařské praxe“. Jsem přesvědčen, že se od té doby imunologie stala nejen respektovaným, svébytným lékařským oborem, ale tím, že je imunita jedním ze základních fyziologických a patologických principů v organizmu, také nedílnou a potřebnou součástí všech medicínských oborů. Nebot', praktický význam imunologie tkví nejen v zajištění diagnostiky a terapie chorob z poruch imunity, ale i v tom, že ukazuje, jak sílit zdravé v jejich zdraví.

Přeji čtenářům časopisu Vnitřní lékařství přínosné čtení, které snad přiblíží „břehy teoretického oboru a lékařské praxe".

Váš

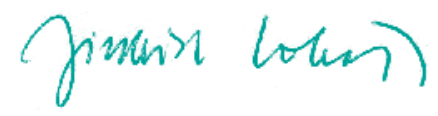

prof. MUDr. Jindřich Lokaj, CSc. spolueditor tohoto čísla časopisu Vnitřní lékařství Brno, únor 2019

\section{Literatura}

1. Janeway CA, jr. Approaching the Asymptote? Evolution and Revolution in Immunology. Cold Spring Harb Symp Quant Biol 1989; 54(Pt 1): 1-13.

2. Jerne NK. The Generative Grammar of the Immune System. Science 1985; 229(4718): 1057-1059.

3. Tlaskalová-Hogenová H, Městecký J. Účast slizničního imunitního systému a komenzálních bakterií v alergii. Alergie 2012; 14(2): 124-133.

4. Morens DM, Folkers GK, Fauci AS. The Challenge of Emerging and Re-emerging Infections Diseases. Nature 2004; 430(6996): 242-249. Dostupné z DOl: <http://dx.doi.org/10.1038/nature02759>. Erratum in Nature 2010; 463(7277): 122.

5. Kaliner MA, Del Giacco S, Crisci CD et al. Requirements for Physician Competencies in Allergy: Key Clinical Competencies Appropriate for the Care of Patients With Allergic or Immunologic Diseases. World Allergy Organ J 2008; 1(2): 42-46. Dostupné z DOI: <http://dx.doi.org/10.1097/ WOX.0b013e3181651689>.

6. Lehmann FM. Die Lösung des Immunitätsproblems. Karger: Berlin 1924.

7. Hegglin R. Differentialdiagnose innerer Krankheiten. Thieme: Stuttgart 1969. ISBN 9783133448147.

8. Lokaj J. Ženy, muži a imunita. Alergie 2015; 17(1): 11-15.

9. Franceschi C, Garagnani P, Vitale G et al. Inflammaging and "Garb-aging". Trends Endocrinol Metab 2017; 28(3): 199-212. Dostupné z DOI: $<$ http://dx.doi.org/10.1016/j.tem.2016.09.005>.

10. Hotamisligil GS. Foundations of immunometabolism and implication for metabolic health and disease. Immunity 2017; 47(3): 406-420. Dostupné z DOI: <http://dx.doi.org/10.1016/j.immuni.2017.08.009>.

11. Zmora N, Bashiardes S, Levy M et al. The role of the immune system in metabolic health and disease. Cell Metabolism 2017; 25(3): 506-521. Dostupné z DOI: <http://dx.doi.org/10.1016/j.cmet.2017.02.006>.

12. Rosas-Ballina M et al. Acetylcholine-synthesizing T cells relay neural signals in a vagus nerve circuit. Science 2011; 334(6052): 98-101. Dostupné z DOI: <http://dx.doi.org/10.1126/science.1209985>.

13. Krejsek J, Andrýs C, Krčmová I. Imunologie člověka. Garamon: Hradec Králové 2016: 319-346. ISBN 978-80-86472-74-4.

14. Höschl C, Horáček J. Duše jako imunomodulátor. Vnitř Lék 2016; 62(11, Suppl 4): 4S36-4S41. 